\title{
A VÁROSREHABILITÁCIÓ HELYZETE BUDAPESTEN
}

\section{SCHNELLER ISTVÁN HOZZÁSZÓLÁSA}

A városrehabilitáció kiemelkedő szerepe, fontossága 1993 (Budapest reneszánszáért) óta szinte minden városfejlesztési, városrendezési és szabályozási (jogi szempontból rendelet) dokumentumban nyomon követhetö. Függetlenül attól, hogy az elvi állásfoglalásokat, koncepciókat, határozatokat és rendeleteket nem mindig követte a gyakorlatban a megvalósításhoz szükséges források, eszközök és szervezetek biztosítása, ill. létrehozása.

A legutóbbi dokumentumokban, így pl. a Hosszú távú városfejlesztési koncepcióban (jóváhagyva 2003), Budapest Településszerkezeti Tervében (megállapítva 2005), a középtávú városfejlesztési programban (alias Podmaniczky program, 2006), a jelenleg érvényben lévö, de most felülvizsgálat alatt álló városépítési keretszabályzatban, a városrehabilitációs keret felhasználásáról szóló rendeletben, (utolsó felülvizsgálat 2005 ősz) egyaránt kiemelt szerepet kap a városrehabilitációs tevékenység ütemének fokozása, mủködési körének kiterjesztése. Az épített környezet minősége, mint a lakható-élhető város értékrendi pillér szerepének biztosítása, mindig is a meglévö, értékes várostest rehabilitálását jelentette e dokumentumok készítőinek szemében. (A városfejlesztési koncepció ugyanis három pilléren nyugvó értékrendre támaszkodott: a hatékonyság-versenyképesség, az élhetöség-lakhatóság és a méltányosság-szolidaritás értékrendjeire.)

Néhány példát idézve az előbbiekbỏl: a fejlesztési koncepció egyik stratégiai célja az épített környezet minőségének javítása, mely stratégiai cél legfontosabb eleme a lakónegyedek, ipari rozsdaövezetek, közterületek stb. rehabilitációja volt. A településszerkezeti tervben kijelölésre kerültek azok a fokozottan karaktervédett területek, melyek megőrizve-megújítása lehet a következő évek egyik legfontosabb, Budapest arculatát a világ felé is megmutató lehetősége. A szabályzatokban pedig a megújulást elősegítendő szabályozástechnikai „bónuszok” kívánták segíteni a rendszerváltás után döntöen magánkézbe került épületállomány megújulását.

A városrehabilitációs keretrỏl szóló rendelet tartalma, a városrehabilitáció folyamatosan felülvizsgált programjának megfelelỏen a komplexitás irányába fejlödött, azaz a kezdetben szinte kizárólag épület felújítási programként múködő eszköz lassan a komplex városrész megújító akciók potenciális eszközévé vált.

Hogy a koncepciójában egyre fejlödő, korszerüsödö rehabilitációs eszkỏzökkel sem sikerült a rehabilitációs tevékenység intenzitását és eredményességét a jelenleginél nagyobb méretekben kiterjeszteni, annak több okára is rámutattak a „Tér és Társadalom" 2006/1-es számának szerzỏi. Írásaik cím és tárgy szerint is körbejárják a rehabilitáció számos kérdéskörét és föként budapesti problémáját. Rámutatnak a rehabilitáció társadalmilag fenntartható folyamatának szükségességére, a rehabilitáció 
fejlesztéspolitikai hátterére, a különböző városrehabilitációs stratégiák egyidejủ jelenlétére, a barnamezös területek rehabilitációjának fontosságára, a slumosodás és a rehabilitáció társadalmi oldalának összefüggéseire stb. Ugyanakkor van néhány olyan kérdéskör, amely a mégoly sokoldalú megközelítés ellenére is szinte kimaradt vagy alulkezelt az itt megjelent írásokban. Pedig a szakma gyakorlóinak, pontosabban a rehabilitáció gyakorlati aprómunkáit végzöknek a tudomány oldaláról éppen ezekben a kérdésekben kellene segítséget kapniuk.

Ezekre a kérdéskörökre szeretném felhívni a figyelmet. Ezek pedig a következök:

1) a rehabilitáció általánosan és elhúzódó módon jelentkezö forráshiánya;

2) a rehabilitáció tekintetében jelentkező, szinte átfogó definíciós pontatlanság;

3) a rehabilitáció beillesztése az átfogó település és területszerkezeti kérdések körébe.

1) A forráshiányról elsősorban annyit kell elmondani, hogy átfogó elemzések mutatták ki, hogy nagyságrendileg a budapesti épületállomány rehabilitációs elmaradása 200-400 milliárd forintot tesz ki. (A fỏépítész iroda megbízásából készült tanulmányt a RévVIII. készítette szakértök bevonásával. A tanulmány abból a célból készült, hogy a kormányzatnak érzékeltetni lehessen a problémamező nagyságát.)

Figyelembe véve, hogy a fỏváros a lakásprivatizáció során a kerületektől befolyt bevétel, a saját költségvetésben biztosított támogatási alap pályázati úton történő elosztásával, a kerületek a saját keretböl jutatott támogatások biztosításával is, mint közösségi szféra mintegy 4-8 milliárd forintot tud a rehabilitáció érdekében megmozgatni, könnyedén levonható az a következtetés, hogy ha ilyen ütemben halad az épületállomány megújítása, akkor hozzávetölegesen 100-200 év szükséges a rehabilitációs elmaradás pótlásához. Ezen idöszak alatt pedig mintegy négy felújítási ciklus elmaradását szükséges még a rendszerbe pótolni.

A helyzet a jelenlegi intenzitás mellett így majdnem reménytelen. Természetesen az épületállomány megújulásához az irodapiac, a banki és szállodai szektor is hozzájárul, valamint a szanálásos-bontásos tevékenységgel megvalósuló lecserélődés következtében létrejövő új épületállomány, azonban kétséges, hogy ezeket a tényezőket mennyire lehet a rehabilitáció körébe számítani. Ezzel pedig lassan áttérhetünk a következö definíciós problémakörre. Mégis azt kell megállapítanunk, hogy a rehabilitáció sebességét nézzük, csak azt mondhatjuk, hogy a remény hal meg utoljára. (És még nem is beszéltünk az ún. rozsdaövezet szervezett és városszerkezeti értelemben súlypontban lévő rehabilitációjáról.)

2) A második kérdéskör a definíciók pontatlansága. Maga a rehabilitáció szó igen sok értelemben használatos, és nemcsak a városi gyakorlat, hanem a kutatás és a fentiekben megidézett cikkek sem kísérelnek meg rendet tenni a kérdésben. Különösen szembetúnő ez, amikor a különbözö városrehabilitációs akcióterületek eltérő stratégiáiról és meglehetősen különböző eredményeiröl beszélünk.

Minek alapján jelölhetö ki egy akció terület, vannak-e objektív kritériumok, indikátorok, amelyek egyértelmüen jelzik a krízisterületeket? 
Mennyire hatják át rövid távú politikai és gazdasági érdekek az egyes akcióterületek kijelölését?

Még bántóbb a helyzet, ha az ún. rehabilitációs célok szempontjából vizsgáljuk a kérdést. Tegyük ugyanis fel, hogy a krízisterületeket egyfajta objektív elemzéssel kiválasztjuk, ekkor még mindig fennmarad kérdés mi legyen a terület sorsa? Egyként tekinthetö az épület felújítás vagy éppen a ,szőnyegbombázás” rehabilitációnak? Nyilván, hogy nem. Pedig szégyenlösen félrenézünk, s ha már kijelöltünk egy akcióterületet, nem vizsgáljuk a rehabilitációs célok és paraméterek teljesülését.

A rehabilitáció véleményem szerint egy városrész karakterét megörző, de a térbeli fellazítását és a lakásállomány korszerüsítését is eredményező megújítást jelenti természetesen fizikai értelemben, társadalmi értelemben pedig a városlakók túlsúlyát a városhasználókhoz képest. E pontatlannak hangzó (építész) definíció után áttérhetünk a rehabilitáció időbeli lefolyásával kapcsolatos problémákra.

Túl azon, hogy meddig tekinthetỏ egy akció terület akcióterületnek, vagyis, hogy milyen gyorsan kell egy akciónak lebonyolításra kerülnie, ehhez a kérdéshez tartozik az is, mit tekintünk lakosságcserének vagy éppen dzsentrifikációnak ebben a tekintetben.

Szubjektív megjegyzésem az, hogy születésem óta ugyanabban a bel-budai bérházban, csak egy nagyobb lakásban élek, és néha azt gondolom - bocsánat ebben a körben - hogy bár csak egy kicsit dzsentrifikálódna az a térség, ahol élek, és ne folyamatosan süllyedne a társadalmi lejtön.

Komolyra fordítva a szót. Nem igazán tudjuk mérni, hogy egy lakosság megtartó rehabilitáció esetén melyik időkeresztmetszet lakosságát kívánjuk megtartani. Még a fentebb hivatkozott tanulmányok is jelzik, hogy a vizsgált területeken elterjedt rehabilitáció, ill. annak hosszú idôszakon keresztüli elhúzódása komoly lakosságcserével, szegényebb rétegek beköltözésével, a társadalmi problémák koncentrálódásával járt. Különösen igaz ez, pl. a középső Józsefvárosra, ahová az elmúlt másfél évtizedben más kerületekböl rehabilitációk során kiszorult népesség költözött, de vizsgálhatnánk ezt tágabb térségben is. Vajon a Budapestet elhagyó városlakó, várost fenntartani képes, szuburbokba kiköltözỏ réteg hol okozott dzsentrifikálódást, pl. Piliscsabán vagy Pilisvörösváron, ahol már el is akarnak szakadni az anyatelepüléstöl, és mivel járt ez az elhagyott budapesti városrészekben. Hogyan alakul a városlakó népesség és a várost „csak” használó ideiglenes vagy nappali népesség aránya?

A városban való lakás feltételezi a fellazított városszövetet, a megfelelö zöldterületi arányt, a széleskörủ napi intézményellátottságot, a forgalomcsillapított környezetet stb. akkor, ha nem csak a diák, a külföldi munkavállaló vagy a mobil egyéni munkavállalókban gondolkodunk.

Készültte valamilyen kutatás e tárgykörben? Mi tehát a dzsentrifikáció? Mihez képest? Milyen várost akarunk? Ahol lehet élni, vagy éppen csak idegenforgalmi látványosságot, ahol a gyalogos utcák kávézói feletti lakosok a területet ugródeszkának tekintik? 
Jó dolog a szociális városrehabilitáció, és fontos is a leglepusztultabb terïleteken, de mit csinálunk a nagyobb tömegü leromlott lakásokat tartalmazó és egyáltalán nem egynemü városrészekkel?

3) A harmadik kérdéskör még bonyolultabb. Milyen tágabb környezetbe illeszkedik a rehabilitálandó terület városszerkezeti közlekedéshálózati szempontból? Mit jelent a kompakt és fenntartható városfejlödésre való törekvés a szuburbanizációval vagy a spontán városfejlödéssel szemben? Mit jelent az intelligens, mobilitásra alapozott városfejlesztés? Hogyan és milyen eszközökkel lehet a Budapest súlypontjában lévő rozsdaövezeteket, átmeneti zónákat integrálni a várostestbe? Hogyan lehet a város zöldfelület ellátását területi tartalékokkal biztosítani, hogyan lehet kihasználni a meglévő intézményhálózatot? Hogyan lehet csökkenteni az utazási távolságokat? Egyáltalán a városszerkezetben való elhelyezkedést figyelembe lehet-e venni a rehabilitáció akcióterületi kiválasztásánál?

Hol segít a puszta közterület-megújítás? Hol jelent rehabilitációt egy-egy közlekedési kapcsolat megvalósítása? Milyen területfelértékelö szerepe van egy-egy jól kiválasztott szabad területnek vagy zöldfelületnek?

Megannyi kérdés vár megválaszolásra! Sőt, alapkutatásokra lenne szuikség, hogy a tényleges helyzetet egy ilyen forráshiányos, politikai és gazdasági szétszabdaltság sújtotta városban megismerjưk, hogy a korlátozottan rendelkezésre álló forrásokat jobban használhassuk fel. 